\title{
PRETRIAL AS A PART OF \\ JUDICIAL CASE MANAGEMENT IN POLAND IN COMPARATIVE PERSPECTIVE
}

\begin{abstract}
In his comparative study, Bartosz Karolczyk focuses on the analysis of procedural provisions pertaining to the preparation of trial. This stage in the proceedings, following its common law origin, is often called pretrial. The goal of this preparatory stage is to increase both the transparency and efficiency (reduce cost, increase accuracy of decisions) of civil litigation.

The author extensively discusses Polish law (in the light of the 2012 amendments), German law and American (federal law). Some references are also made to Norwegian law and Lithuanian law. The purpose of the analysis is to synthesize existing trends and the essential elements of effective pretrial regulations. This requires reconstruction of the sequence of procedural actions taken by the court and the parties, as well as the relationship between them and the actors.

In conclusion, the author recaps his findings. In addition, by putting forth three theses he identifies the main challenges to the evolution of Polish procedure in accordance with European trends. He concludes with specific recommendations for the Polish legislator.
\end{abstract}

\section{Keywords}

Polish civil procedure - German civil procedure - Norwegian civil procedure - American civil procedure - judicial case management - pretrial - active judge - duty to support the proceedings party cooperation with the judge - efficiency

\footnotetext{
Researcher at Ius Commune Research School, Maastricht, the Netherlands. Ph.D. (College of Law, Koźmiński Academy in Warsaw, 2013); LL.M. (George Washington University Law School, 2007), Master of Laws (Faculty of Law and Administration, Warsaw University, 2005). Attorney at law (Poland, Warsaw Chamber of Advocates).

This paper is heavily based on selected sections from B. Karolczyk, Koncentracja materiatu procesowego w postępowaniu cywilnym przed sądem pierwszej instancji. Analiza porównawcze na przykładzie prawa polskiego oraz prawa federalnego USA [Concentration of Procedural Material in Trial Court. Comparative Analysis of Polish and American Law), Warszawa: Wolters Kluwer 2013.
} 


\section{INTRODUCTION}

This article examines how a civil case gets prepared for trial in four jurisdictions, namely Poland, Germany, Norway, and the USA.

Trial court proceedings resemble a process we utilize daily whenever faced with an important decision. What we need or expect, usually fast and preferably in advance, is reliable information. This is pretty much self-explanatory - the less information is available to the judge or the parties, the more likely it is that the case will take longer to decide and its accuracy will be adversely affected. Moreover, lack of reliable information hinders the settlement process and thus necessitates conclusion by a judgment. The longer it takes, the more expensive it becomes, for both the state and the parties. Given the above - and the goal of civil process in the social model of procedure ${ }^{1}$, which is to decide the case properly without undue delay - it is reasonable to say the following: procedure at the trial (first instance) courts should primarily facilitate identification, and collection and exchange of information ${ }^{2}$, and its subsequent exchange between the actors ${ }^{3}$. This process should be planned in advance and actively managed by a centralized authority.

Together with requiring the parties to promote the efficiency ${ }^{4}$ of the proceedings, introduction of judicial case management has been a popular

1 Cf. generally M. Damaška, Faces of Justice and State Authority. A Comparative Approach to Legal Process, New Haven: Yale University Press 1986 (creating a distinction between conflict-solving model and policy-implementing model of procedure).

2 In Polish doctrine, information collected throughout the proceedings has been traditionally divided into two categories, namely: 1) facts alleged by the parties ("factual material"), and 2) information that is used to verify the truthfulness and accuracy of factual allegations ("evidentiary material" or simply "evidence"). Jointly, these two are commonly referred to as "procedural material".

3 What I do not discuss here is how civil procedure should respect or implement the idea that the cost of information should be as low as possible.

4 Procedurally, in Europe this concept has two elements. First, cases should be decided within reasonable time and as economically as possible. Second, cases should be decided fairly on the merits, that is, in accordance with substantive law. See M. Taruffo, Orality and Writing as Factors of Efficiency in Civil Litigation, [in:] F. Carpi, M. Cartells (eds.), Oral and Written Proceedings: Efficiency in Civil Procedure, vol. 1, Valencia: Universitat de València 2008, p. 187; P. Pogonowski, Realizacja prawa do sądu w postępowaniu cywilnym [Right to Court in Civil Proceedings], Warszawa: C. H. Beck 2005, p. 61 and A. Łazarska, Rzetelny proces cywilny [Fair Civil Process], Warszawa: Wolters Kluwer 2012, p. 379 et seq. Cf. the overriding objective of the English Civil Procedure Rules in Rule 1.1, available at 
trend in Europe in recent years ${ }^{5}$. The concept ${ }^{6}$ has gained tremendous popularity in part due to the Woolf Reform 7 . As a result of its success, judicial case management has become one of the main themes in the European discussion about improving the efficiency of the civil justice system. The relative freedom of the judge in managing the proceedings is currently considered the best method to achieve this goal ${ }^{8}$. Flexibility is ensured by allowing the court (or the judge) to exercise (judicial) discretion pursuant to standards rather than rules. This, however, should be done with due regard for fundamental procedural principles of a given

http://www.justice.gov.uk/courts/procedure-rules/civil/rules/part01 [last accessed: 27.04.2013].

5 The literature is vast. See A. A. P. Zuckerman, Justice in Crisis: Comparative Dimensions of Civil Procedure, [in:] A. A. P. Zuckerman (ed.), Civil Justice in Crisis: Comparative Perspectives of Civil Procedure, Oxford, New York: Oxford University Press 1999, pp. 47-48 (noting the universal assertion of judicial control and suggesting the emergence of a new philosophy of procedure and adjudication); C. H. van Rhee, Introduction, [in:] C. H. Van Rhee (ed.), Judicial Case Management and Efficiency in Civil Litigation, Antwerp: Intersentia 2008, p. 21; K. Å. Modéer, Delay and Judicial Culture in Sweden, [in:] C. H. Van Rhee (ed.), The Law's Delay. Essays on Undue Delay in Civil Litigation, Antwerp: Intersentia 2004, p. 202; R. R. Verkerk, Fact-Finding in Civil Litigation: A Comparative Perspective, Maastricht: Intersentia 2010, p. 61 (reporting on developments in the Netherlands); A. W. Jongloed, The Netherlands (1838-2005), [in:] C. H. Van Rhee (ed.), European Traditions in Civil Procedure, Antwerp: Intersentia 2008, pp. 92-93; R. Verkijk, Beyond Winning: Judicial Case Management and the Role of the Lawyers in the Principle of Transnational Civil Procedure, [in:] C. H. van Rhee (ed.), Judicial Case Management, supra note 5, pp. 64-65 and I. L. Becker, The Norwegian Reform of Civil Procedure, [in:] V. Lipp, H. Fredriksen (eds.), Reforms of Civil Procedure in Germany and Norway, Tübingen: Mohr Siebeck 2011, p. 74.

6 There have been many attempts at synthesizing its theoretical elements. See for example D. Leipold, Oral and Written Elements Within the Introductory Phase of Civil Procedure, [in:] Carpi, Cartells (eds.), supra note 4, p. 53 (noting that the concept rests on various methods of advanced planning of litigation schedule) and R. R. Verkerk, What Is Judicial Case Management? A Transnational and European Perspective, [in:] van Rhee (ed.), Judicial Case Management, supra note 5, pp. 42-43.

7 See L. Woolf, Access to Justice: Interim Report, London: The Stationary Office 1995, chap. 4 and L. Woolf, Access to Justice: Final Report, London: The Stationary Office 1996, p. 5. At the same time, it has reinvigorated historical procedural scholarship since the idea can be easily linked to the thought of Franz Klein, a great $19^{\text {th }}$ century Austrian reformer.

8 See Leipold, supra note 6, p. 78; Taruffo, supra note 4, p. 204. See also generally contributions in Rhee (ed.), Judicial Case Management, supra note 5. For various reasons, American authors are slightly less enthusiastic. For details see J. Resnik, Managerial Judges, Harvard Law Review 1982-1983, vol. 96, pp. 380, 424 et seq.; R. L. Marcus, Malaise of the Litigation Superpower, [in:] Zuckerman (ed.), supra note 5, p. 110. 
legal order, the particular circumstances of the case, as well as the parties' legitimate interests 9 .

Without question, the comparative approach to law enhances the analysis of and search for the best legislative solutions. It makes it possible to counter a very old and basic bias ${ }^{10}$ in thinking, which was aptly described by Sir F. Bacon many centuries ago: "But much the greatest obstacle and distortion of human understanding comes from the dullness, limitations and deceptions of the senses; so that things that strike the senses have greater influence than even powerful things which do not directly strike the senses. And therefore thought virtually stops at sight; so that there is little or no notice taken of things that cannot be seen"11.

In the pages that follow I discuss selected elements of Polish, German, Norwegian and Lithuanian pretrial procedure. In the second part of the article I follow this approach with regard to pretrial under the American Federal Rules of Civil Procedure ${ }^{12}$. Given this comparative method, the ultimate outcome of this short study is an attempt to synthesize existing lines of thought in the modern approach to pretrial rules, especially in the context of Polish law. Additionally, I make some de lege ferenda recommendations for the Polish legislator.

9 Cf. B. Cardozo, The Nature of the Judicial Process, New Haven: Yale University Press 1921, p. 141 (a very famous paragraph on judicial discretion in American jurisprudence). See also R. Dworkin, Taking Rights Seriously, Cambridge, Massachusetts: Harvard University Press 1977, pp. 31-39 (discussing weak and strong judicial discretion in the context of legal positivism).

10 This bias is recognized by modern science. See D. Kahneman, Thinking, Fast and Slow, New York: Gerrar, Strauss and Geroux 2011, pp. 129-136 (explaining the availability heuristic as a systemic error in exercising intuitive judgment).

11 F. Bacon (eds. L. Jardine, M. Silverthorne), The New Organon, New York: Cambridge University Press 2000, p. 45.

12 Modern Polish research into this area has been, until very recently, basically non-existent. For a more comprehensive rationale for comparative law research into common law procedure see B. Karolczyk, Koncentracja materiatu procesowego w postępowaniu cywilnym przed sądem pierwszej instancji. Analiza porównawcze na przykładzie prawa polskiego oraz prawa federalnego USA [Concentration of Procedural Material in Trial Court. Comparative Analysis of Polish and American Law], Warszawa: Wolters Kluwer 2013, pp. 33-38. 


\section{Pretrial in Polish Civil Procedure: A CRitical overview}

When I look at the sequence of provisions regarding first instance proceedings in the Polish Code of Civil Procedure (the "CCP")13, they strike me as a bit odd. Specifically, in Part II (first instance proceedings) we find two chapters - chapter 2 titled "Complaint" and subsequent chapter 3, titled "Main Hearing"14. This would suggest that main hearing is held after the complaint is filed with the court, which is, strictly speaking, not the case. However, given the existing practice of many Polish trial courts, this is not far from the truth. Moreover, what this clearly indicates is a structural lack of a pre-trail stage in Polish civil procedure. There are many random provisions after Article 187 (stipulating mandatory, formal requirements of a complaint), that do not seem to fit into this chapter at all. Let me also note that there are absolutely no deadlines for specific court actions, like service of the complaint ${ }^{15}$, scheduling of the main hearing or commencement of the trial. Furthermore, the CCP does not mention preparation of the schedule of the proceedings or the trial plan, which could then be used as a roadmap for subsequent steps in the litigation ${ }^{16}$. So, regardless of many similarities between a complex court case and other complex forms of human activity (e.g. planning or financing of complicated ventures that require participation of multiple actors and spread across

\footnotetext{
13 References to Articles of law in this study are to CCP, unless otherwise indicated.

14 This is a literal translation of the Polish term "rozprawa". However, I will also frequently use the term "trial" as it pretty much represents the same idea. It should be noted that trials in Poland are divided into many hearings over the course of several months (piecemeal trial). In comparative literature, cf. Damaška, supra note 1, pp. 51-53.

15 Neither CCP, nor any other normative act that deals with courts provides for such deadlines or schedule. The complaint is served by the court through the use of registered mail. It requires confirmation of receipt.

16 Practically, this is sometimes done, but usually in complete secrecy and the intentions of the judge are not revealed to the parties, who have no clue how many hearings there will be, etc. Thus, the proceedings are basically non-transparent. Not surprisingly, these flaws are in line with the socialist legal tradition in the area of procedure. See A. Uzelac, Survival of the Third Legal Tradition, Supreme Court Law Review 2010, vol. 49 (2d), p. 390 (identifying, inter alia, lack of planning and procedural discipline, as well as lack of trial in the proper sense as elements of socialist legal tradition, which continues to exist in Central and Eastern European countries despite the fall of socialism). Cf. also A. Galič, A Judge's Power to Disregard Late Facts and Evidence and the Goal of Civil Justice [in:] Recent Trends in Economy and Efficiency of Civil Procedure. Materials of International Conference 9-10.05.2013, Vilnius: Vilnius University Press 2013, pp. 85-95.
} 
long periods of time), it is fair to say that in an average Polish court nobody sees any plans or schedules of what lies ahead in the litigation.

Indeed, the CCP neither contains the term "pretrial" or "preparation of process" (pol. przygotowanie procesu), nor does it recognize preparation of the main hearing as a separate stage ${ }^{17}$. As already mentioned, it is clear that structurally there is no pretrial stage in the $\mathrm{CCP}^{18}$. To a certain degree this is a legacy of the line of thought that began in 1920's when it was concluded that pretrial is unwarranted and in fact detrimental to the efficiency of litigation ${ }^{19}$. Still, this approach has been increasingly criticized over the last several years ${ }^{20}$.

On the other hand, the phrase "preparation of the main hearing" can be found in the CCP. Moreover, preparation of proceedings, usually understood as all actions by the court or the presiding judge taken in order to ensure swift and fair disposition of a case ${ }^{21}$, is recognized in legal doctrine as having a bearing on its outcome. In the old literature it was argued that preparation of proceedings cannot be regulated exhaustively and in detail because the scope of the court's activity and the manner

17 See P. Hanausek, Przygotowanie procesu cywilnego [Preparation of Civil Process], Nowe Prawo [New Law] 1964, issue 2, p. 160. Cf. K. Kołakowski, Dowodzenie w procesie cywilnym [Proof in Civil Process], Warszawa: Wydawnictwo Zrzeszenia Prawników Polskich 2000, p. 61.

18 See P. Dmowski, K. Kołakowski, [in:] K. Piasecki (ed.) Kodeks postępowania cywilnego. Komentarz [Code of Civil Procedure. Commentary], vol. I, Warszawa: C. H. Beck 2010, p. 1171 (with reference to Article $201 \S 1$ ). See also Łazarska, supra note 4, p. 414. The case is different in employment cases, where investigative steps are provided for. See Article 468.

19 See S. Gołąb, Projekty polskiej procedury cywilnej, Powstanie - uzasadnienie - zdania odrębne [Drafts of Polish Civil Procedure: Drafting, Explanation, Dissenting Opinions], Kraków: Księgarnia Powszechna 1930, p. 87 (explaining that the draft of the Code of 1930 did not contain pretrial provisions, because the drafters believed they were unwarranted, would delay the proceedings and in fact go against the procedural principles on which the Code was based).

20 See P. Osowy, Zapobieganie przewlekłości postępowania cywilnego z uwzględnieniem znaczenia zasady koncentracji materiatu procesowego (zagadnienia wybrane) [Prevention of Delay in Civil Proceedings and the Principle of Concentration of Procedural Material], Rejent [Notary] 2002, issue 11, p. 149; P. Rylski, Aktywność sądu w zakresie zbierania materiatu faktycznego sprawy w przygotowawczej fazie postępowania cywilnego (art. $207 \S 2$ i 3 KPC) [Judicial Activity in Fact-Finding During the Pretrial Stage in a Civil Case], [in:] H. Dołecki, K. FlagaGieruszyńska (ed.), Materiały konferencyjne Ogólnopolskiego Zjazdu Katedr Postępowania Cywilnego Szczecin-Niechorze 28-30.9.2007 [Conference Materials from the Polish Convention of Procedural Chairs], Warszawa: C. H. Beck 2009, p. 398; A. Łazarska, Sędziowskie kierownictwo postępowaniem [Judicial Management of Proceedings], Przegląd Sądowy [Judicial Review] 2012, issue 5, p. 61.

21 In the older literature the preparation of the civil process was defined as all actions by the court that indirectly facilitate the resolution of the case. See Hanausek, supra note 17, p. 160. 
or form it takes depend on the specific circumstances of each case ${ }^{22}$. As a result, the view was that "in principle, there can be no deadline (for preparation of civil process), because preparatory actions can be taken during the entire proceedings, so not only prior to judgment, but even after it became final, during the enforcement stage" 23 .

Not merely due to changes in the law, these views are not longer valid. In fact, they represent a perfect example of how "dogmatic law" can defy logic or reason.

It is clear today that trial should not begin, unless the case has been well prepared ${ }^{24}$. What follows is that, in principle, preparations for trial should stop once the trial has commenced ${ }^{25}$. As already explained, it is only logical that a filtered and concentrated pool of information (allegations and evidence) facilitates the decision-making process (judgment). If this pool is small, it may be impossible to reach a decision or its quality may be questionable. In addition, the search for data may reveal that there are no material facts that are actually in dispute between the parties. Lack of preliminary examination of the case by the judge and the necessary direction in which the collection of evidence should precede will ultimately

22 See Hanausek, supra note 17, p. 160. This was largely due to the wording of provisions in force at the time. Specifically, Article 3, 213 and 232. The court should examine all material circumstances of the case in a comprehensive manner and discover the actual substance of factual and legal relations. The court, acting on its own, may take any steps allowed, given the stage of the proceedings, deemed necessary to supplement the [factual] material and evidence submitted by the parties (Article $3 \S 2$ ). Pursuant to Article $213 \S 1$, the court could order an appropriate inquiry in order to supplement or clarify the parties' allegations. Moreover, in principle, the court was not bound by the defendant's acceptance of the complaint. Pursuant to Article 232 the parties are (still) obliged to submit evidence necessary to decide the case. However, the court could take evidence not submitted by the parties; the court could also order an appropriate inquiry so that necessary evidence could be established.

23 Hanausek, supra note 17, p. 161. This is in line with another feature of the socialist legal tradition, namely the pursuit of material truth. Cf. Uzelac, supra note 16, p. 390 and Galič, supra note 16, p. 94 .

24 This has been noted by many authors on many occasions. Unfortunately, this (purportedly) legislative intent is commonly ignored in practice due to a "mistaken belief that it is more important to "set the date» and question the parties" [than to properly prepare the case for trial]. Osowy, supra note 20, p. 147

25 Cf. P. Rylski, Działanie sądu z urzędu w zakresie ustalenia podstawy faktycznej rozstrzygnięcia $w$ procesie cywilnym [The Court Acting on Its Own Initiative and Fact-Finding in Civil Litigation], Warszawa: Wolters Kluwer 2009, p. 224 (recommends focusing more on proper preparation for trial and thus the use of Article 207 in its former wording) and P. Dmowski, K. Kołakowski, [in:] Piasecki (ed.), supra note 18, p. 1208 (critique of S. Gołąb). 
backfire and prove wasteful ${ }^{26}$. What we are dealing with here is lack of transparency and lack of information-flow.

Service of the complaint is a good example. Very often it is served together with an order setting forth the date of the first hearing in the trial27. In other words, courts have been regularly setting this date without even seeing the defendant's answer ${ }^{28}$.

Trials in Polish courts are routinely unprepared ${ }^{29}$, although exceptions exist. How can it be otherwise, if the initial questioning of the parties ${ }^{30}$, should they care to attend, takes place at first hearing? As noted by practicing judges, it is simply impossible to determine material facts and evidence at the first hearing (through questioning of the parties) simply owing to lack of information ${ }^{31}$. As a result, the first hearing is actually used to prepare only the next one, but not the entire trial (piecemeal preparation) $)^{32}$.

26 See Osowy, supra note 20, pp. 147-148; Łazarska, supra note 20, p. 66. The approach to adjudication with the judge as the intellectual nexus has its own challenges pertaining to psychology and the decision-making process. For a mention of this problem see M. Damaška, Evidence Law Adrift, New Haven: Yale University Press 1997, pp. 94-98.

27 See Article 206 § 1. See T. Żyznowski, [in:] H. Dolecki, T. Wiśniewski (eds.), Kodeks postepowania cywilnego. Komentarz. Tom I. Artykuty 1-366 [Code of Civil Procedure. Commentary. Vol. I], LEX 2011 (online commercial database); W. Broniewicz, Postepowanie cywilne w zarysie [Outline of Civil Procedure], Warszawa: LexisNexis 2008, p. 211; T. Wiśniewski, Przebieg procesu cywilnego [The Sequence of Civil Litigation], Warszawa: Wolters Kluwer 2008, p. 149; Łazarska, supra note 4, p. 414. Cf. M. Jędrzejewska, K. Weitz, P. Grzegorczyk, [in:] T. Ereciński (ed.), Kodeks postępowania cywilnego. Komentarz [Code of Civil Procedure. Commentary], vol. 1, Warszawa: LexisNexis 2012, p. 985.

28 See Łazarska, supra note 20, p. 61. Under current law the answer is still not mandatory. The defendant should submit one, if the presiding judge has ordered him to do so. See Article $207 \S 1$.

29 Cf. Łazarska, supra note 20, p. 61 ("the current model of procedure (...) does not warrant effective preparation and adjudication of cases").

30 This is not considered taking of evidence (testimony). Parties may be questioned by the court with regard to allegations and evidence, but this is done in order to get general understating of the matter. See Article $212 \S 1$.

31 See Łazarska, supra note 20, pp. 64-65 (who believes that the recent amendments will allow for proper preparation of the first hearing, while the current inability to do so is one of main flaws of Polish procedure).

32 See Łazarska, supra note 4, p. 414. As mentioned, this is in line with the socialist legal tradition, namely the feature of deconcentrated proceedings, and a lack of trial in the proper sense. Cf. Uzelac, supra note 16, p. 390 and Galič, supra note 16, p. 95. 
Polish law in this area has been lagging behind many European systems ${ }^{33}$ which usually use a combination of two pretrial tools, namely pretrial hearings (conference) or preparatory submissions. As far as the former is concerned, these are basically meetings between the judge and the parties or their attorneys that take place after the answer has been submitted. As for the latter, having received both the complaint and the answer, the judge may nonetheless order the parties to submit their further observations in writing. These submissions are usually limited in number and content. Having read the pleadings, the judge makes a preliminary assessment of the case and decides which technique will be best to prepare it for trial and how to organize the proceedings. In order words, he actively manages the case. Thus the phrase "judicial case management". The pretrial stage is used to discuss and tentatively establish the factual and legal framework of the dispute, consider settlement options, and agree on the schedule ${ }^{34}$. This approach to trial preparation is discussed in greater detail below.

\section{TRIAL PREPARATION}

\section{PRELIMINARY REMARKS}

Trial preparation is universally recognized as a fundamental factor affecting the efficiency of civil litigation. Still, it has not been thus far a keen subject in Poland. As a matter of fact, not a lot has been written in leading

\footnotetext{
33 See V. Nekrošius, Postępowanie cywilne: zasada koncentracji postępowania cywilnego i możliwości jej realizacji. Streszczenie [Civil Procedure: Concentration Principle and the Possibilities of Its Implementation. Summary], Wilno 2002 (typescript), pp. 61-63 (comments under Lithuanian law); Verkerk, supra note 5, pp. 2, 39 (comments on the 2002 reform of the Austrian civil procedure) and pp. 55, 64 (comments on the 2002 reform of the Dutch system); Becker, supra note 5, p. 57 (comments on Norwegian system which now clearly distinguishes between trial and pretrial) and Łazarska, supra note 20, p. 58 et seq.

34 See $\S 257$ and $\S 258$ of the Austrian ZPO. Recent amendments are founded on the thought of Franz Klein, who preferred pragmatism as far as determination of facts and presentation of evidence were concerned. See Verkerk, supra note 5, p. 39 (citing F. Klein, Vorlesungen über die Praxis des Civilprocesses, Vienna 1900, p. 148).
} 
books ${ }^{35}$ and the existing discussion is painfully general. Its core revolves around the preparatory actions of the presiding judge (see below).

Due to the slow changes in both law and legal culture, the legislator has only recently recognized that trial preparation does not solely depend on the judge, but it is also greatly affected by the parties' conduct. Accordingly, a new procedural burden has been introduced to the CCP in 2012, namely the duty to support the proceedings ${ }^{36}$. As the principle of judicial direction and the adversary system ${ }^{37}$ are, doctrinally, fundamental to Polish procedure, in theory these elements supplement each other. Nevertheless, a curious mind needs to ask whether the CCP really allows for an efficient, joint preparation of the main hearing. In other words, who can do what in order to expand the pool of information available at trial and, ultimately, required for a swift and fair judgment?

\section{ACTIONS BY THE PRESIDING JUDGE}

As already noted, the existing practice in many courts is to serve the complaint upon the defendant together with the order setting forth the date of the first trial hearing. However, unlike in American or English law, in Poland there are no provisions regarding deadlines for service of the complaint, the start of the trial or any scheduling of the proceedings ${ }^{38}$.

\footnotetext{
35 See W. Berutowicz, Postępowanie cywilne w zarysie [Civil Procedure. An Outline], Warszawa: Państwowe Wydawnictwo Naukowe 1974, pp. 262-66; H. Pietrzkowski, Metodyka pracy sędziego w sprawach cywilnych [Judge's Manual in Civil Matters], Warszawa: LexisNexis 2009, p. 319; Broniewicz, supra note 27, pp. 211-212; Wiśniewski, supra note 27, pp. 157-160; B. Bladowski, Metodyka pracy sędziego cywilisty [Manual of a Civil Judge], Warszawa: Wolters Kluwer 2009, pp. 113-125; J. Jodłowski (ed.), Postępowanie cywilne [Civil Procedure], Warszawa: LexisNexis 2009, p. 354. As far as the role of an attorney is concerned, preparation of trial is completely ignored. See generally H. Pietrzkowski, Czynności zawodowego petnomocnika w sprawach cywilnych [Attorney at Law in Civil Matters], Warszawa: LexisNexis 2010.

36 New Article $6 \S 2$ reads: Parties and participants in the proceedings are under the duty to submit allegations and evidence without delay, so that the proceedings can be concluded efficiently and swiftly.

37 Under CCP Article 232 parties must present evidence in support of their allegations which affect their legal position. The court may, however, admit and take evidence not submitted by a party.

38 Since it is outside the scope of this article, I will only note that examination of certain formal circumstances may precede the service of the complaint. See CCP Article 199 and 202.
} 
Next, there is Article 207, which was heavily amended on 3 May 2012.

First of all, the defendant may submit an answer prior to the first trial hearing $(207 \S 1)^{39}$. The presiding judge may, however, order the defendant to file it within a certain time, not less than two weeks (207 § 2).

Moreover, the unlimited freedom of the parties to file preparatory written submissions has been rightly eliminated due to abuse. Now, pursuant to Article $207 \S 3$ any such submission requires the prior approval of the presiding judge or the court ${ }^{40}$. So, the judge may order the parties to file preparatory submissions and stipulate the sequence, time limits and subject matter thereof. Pursuant to Article $207 \S 4$ the judge may also hold a closed hearing during which the contents of his or her order will be determined. Unless prior approval is obtained, any such papers will be returned (rejected) ${ }^{41}$. In other words, the judge now controls the exchange of information in the (pretrial) proceedings ${ }^{42}$. Control is clearly an element of management.

Given the parties' duty to allege facts and identify evidence without delay $^{43}$ the lawmaker seems to prefer written elements as preparatory tools.

If found or lacking, the complaint may be dismissed on formal grounds (pol. odrzucenie pozwu). However, since the court must examine most of these on its own, objections based thereon can be raised and argued until the end of the trial and are not subject to preclusion.

39 The defendant can submit an answer one day prior to the hearing, thus in fact obstructing the trial. Such an actions can be arguably sanctioned as against established practice (CCP Article 3) and the duty to support the proceedings (CCP Article $6 \S 2$ ). Cf. remarks by K. Weitz, P. Grzegorczyk, [in:] Ereciński (ed.), supra note 27, p. 993. The lack of answer renders the commencement of the trial questionable.

40 However, for reasons I do not understand, the term "permission" has been adopted in the first order of the Supreme Court pertaining to this provision. See Supreme Court order of 13.12.2012 r. (III CSK 300/12), Orzecznictwo Sądu Najwyższego - Izba Cywilna [Decisions of the Supreme Court - Civil Chamber; OSNC] 2013, issue 3, item 42.

41 See CCP Article $207 \S 7$. This provision has been a subject of controversy even at the legislative stage. It has been commonly viewed as an undue limitation on the right to have one's case presented to the court. These views, in my opinion, were and remain unfounded.

42 See for a more detailed discussion K. Weitz, P. Grzegorczyk, [in:] Ereciński (ed.), supra note 27, p. 1000.

43 See CCP Article $6 \S 2$, supra note 35. That duty is further exemplified by the duty to make comprehensive and complete submissions of facts and evidence in the pleadings (complaint and answer, respectively). Pursuant to CCP Article $207 \S 6$ the court ignores untimely allegations and evidence, unless the moving party can show with high probability (lat. semiplena probatio) that their omission from the complaint, answer or other preparatory submission has not been negligent, their admission shall not delay the disposition of the case or other extraordinary circumstances exist. A similar provision has been introduced at the trial stage. See Article $217 \S 2$. 
Accordingly, I would argue that the parties have a right to expect that the judge will now carefully read the pleadings and all subsequent written submissions, if any, and "come up with an action plan" 44.

This is theory. The option to hold a closed hearing, whenever needed, already exists in the CCP45. Arguably, therefore, Article $207 \S 4$ is superfluous and I fear its introduction might not influence the preparation of the trial at all. The main reason for this hypothesis is the observation of existing judicial practice. Nor will one find any indications in the literature that Article $149 \S 1$ is used to that effect ${ }^{46}$. Quite on the contrary, while likely functional in increasing efficiency, Article $149 \S 1$ is essentially ignored in practice ${ }^{47}$. Even the Supreme Court has described the ability to summon a party for questioning at a closed hearing as "entirely forgotten in judicial practice" 48 . In addition to these existing habits there are other challenges this new provision will face.

Currently, the judge, assuming he or she has in fact ordered a closed hearing in order to discuss the preliminary matters, is: (a) unable to sanction unprepared parties or attorneys; and (b) not allowed to rule on evidentiary motions ${ }^{49}$.

\footnotetext{
44 See Pietrzkowski, supra note 35, pp. 322, 324 (stressing the significance of the pleadings for the tentative understanding of the case by the judge), and Bladowski, supra note 35, pp. 113-114. Cf. resolution by all the judges of the Supreme Court of 15.07.1974, KwPr. 2/74, Orzecznictwo Sądu Najwyższego - Izba Cywilna [Decisions of the Supreme Court - Civil Chamber; OSNC] 1974, no. 12, item 203 (point V).

45 See CCP Article $149 \S 1$ (the presiding judge may hold a hearing on his or her own, whenever the case requires it).

46 Who is summoned to the private hearing, is up to the presiding judge. Cf. A. Zieliński, Komentarz do 152 k.p.c., [in:] A. Zieliński (ed.), Kodeks postępowania cywilnego. Komentarz [Code of Civil Procedure. Commentary], Warszawa: C. H. Beck 2009 (“(...) in principle, neither the parties, nor other participants or third parties participate in closed hearings").

47 See K. Kołakowski, [in:] Piasecki (ed.), supra note 18, pp. 790, 796, 1203.

48 See Supreme Court order of 5.02.1999 r., II CKN 1211/98, Orzecznictwo Sądu Najwyższego - Izba Cywilna [Decisions of the Supreme Court - Civil Chamber; OSNC] 1999, no. $7-8$, item 139 .

49 The court may not rule on evidence outside of the trial, with the exception of rulings on expert witnesses. See P. Rylski, [in:] Ł. Błaszczak, K. Markiewicz, E. Rudkowska-Ząbczyk (eds.), Dowody w postępowaniu cywilnym [Evidence in Civil Procedure], Warszawa: C. H. Beck 2010, p. 314. Thus, as hinted above, such rulings, relevant only to the subsequent hearing, will be made at the first hearing (of the trial).
} 
Unfortunately, members of the trial bench have reminded us about all these limitations while commenting on the new law ${ }^{50}$. Apparently, litigants in Polish courts should forego any hope of the judge actually following the case right from the get-go since "the judge can attend the case carefully only prior to the first trial hearing" 51 . Moreover, the expectation of a meeting between the judge and the parties or their attorneys at a closed hearing has been described as "unrealistic". This is because fixing a date for and holding such hearing "cannot be done under the conditions in which Polish courts work"52. Four arguments have been put forth by judge Ł. Piebiak, an author of these views. First, he does not know what these hearings should look like. Second, these hearings cannot be, in principle, recorded in regular transcript ${ }^{53}$. Third, should a party fail to attend, it will render any attempt at fixing a schedule for written submission meaningless. Fourth, in any case, there is no way a judge can force a party to attend. Accordingly, and in the light of existing practice, it is indeed likely that Article $207 \S 4$ will become a dead letter of the law.

Back to theory and the role of the presiding judge. Pursuant to Article 208 prior to the first trial hearing the presiding judge issues preparatory orders. In particular, all the while considering the parties' motions for evidence, he or she may:

1) order the parties to appear personally or through an attorney ${ }^{54}$,

\footnotetext{
50 See Ł. Piebiak, Nowelizacja Kodeksu posteppowania cywilnego - uwagi praktyczne, cz. II [Amendments to the Code of Civil Procedure - Practical Observations, Part II], Monitor Prawniczy [Legal Monitor] 2012, no. 13, pp. 686-688.

51 See ibid., p. 687. Cf. disheartening comments in Łazarska, supra note 4, p. 418.

52 What this means is the lack of actual space to hold such hearing. It is also my personal observation, that judges in Polish trial courts, at least in Warsaw, do not have chambers, as understood in Western culture. They are literally crammed into tiny spaces, oftentimes with another person in the room. Thus, holding these meeting in the "chambers" is indeed impossible. As for holding them in the trial rooms, their capacity is arguably fully used for trial hearings.

53 See Article 157 \& 3. Apparently, this issue is now debated in the doctrine. See Piebiak, supra note 50, p. 687 , footnote 46 .

54 Under Polish law the parties are notified about the trial hearings, because there is no general duty to attend. This produces truly unfortunate results, both sociologically and economically. Cf. remarks by an anonymous trial judge on his popular blog regarding ten hearings in ten different trials on a random day, which not a living soul attended. Available at http://sub-iudice.blogspot.be/2011/07/stawiennictwo-nieobowiazkowe.html [last accessed: 27.04.2013]. Although the court may order personal appearance for initial questioning or taking of testimony, there is no meaningful sanction for failure to comply with
} 
2) order that evidence in possession of state or local authorities be delivered to the court, if the party may not obtain such evidence herself,

3) summon witnesses called by the parties,

4) summon expert witnesses the parties have jointly called,

5) order that documents, items to be inspected, books, plans etc. be produced.

Moreover, the presiding judge may inspect a piece of evidence prior to trial, if necessary (Article $208 \S 2$ ).

All these orders are issued on the basis of information included in the initial pleadings and preparatory submissions, if such have been allowed ${ }^{55}$. Given the policy expressed in Article $6 \S 1$, as far as issuing preparatory orders is concerned the judge should be particularly active ${ }^{56}$. In the words of another author, proper preparation of trial requires "giving thought to and planning out [the sequence of] procedural acts [in the proceedings]", especially with regard to the taking of evidence ${ }^{57}$. Even as (relatively) late as this in the proceedings, a preliminary formal control of the complaint can still occur ${ }^{58}$.

All in all, it is fair to say that Article 206, 207, 208 and 212 stipulate a wide array of rights and duties of the presiding judge. They may be regarded as manifestation of both the principle of judicial direction and the principle of concentration ${ }^{59}$. In fact, it is primarily the judge that is intellectually and organizationally primarily responsible for the preparation of the trial ${ }^{60}$. Apart from submitting relevant or required information at the pleading stage, parties generally do not participate

such an order. See Wiśniewski, supra note 27, p. 158. Attendance is mandatory in matrimonial cases, custody cases and employment cases. See Articles 429, $574 \S 1$ and 475, respectively.

55 Cf. P. Dmowski, K. Kołakowski, [in:] Piasecki (ed.), supra note 18, p. 1216.

56 See Broniewicz, supra note 27, p. 212.

57 See Wiśniewski, supra note 27, p. 157.

58 Ibid., p. 160. Such, indeed untimely, control can result from lack of diligence or lack of information. Cf. supra note 38 .

59 Doctrinally they may be regarded as a manifestation of both the principle of judicial direction and the principle of concentration. Cf. similarly K. Weitz, P. Grzegorczyk, [in:] Ereciński (ed.), supra note 27, p. 989.

60 See e.g. Wiśniewski, supra note 27, p. 157; Pietrzkowski, supra note 35, p. 324. Cf. Supreme Court judgment of 14.03.2001, II UKN 269/00, LEX no. 551028, where the court argued that CCP Article $208 \S 1$ does not place any specific duties on the presiding judge. 
in this process. According to one of the leading commentaries, the purpose of Article 207 is to allow the court to "obtain a tentative understanding of the character and scope of disputed matters", evidence and the need for initial questioning of the parties ${ }^{61}$. Thus, how well the trial is prepared depends heavily on the activity and prudence of the presiding judge (or the lack thereof). Except for the information exchanged at the pleading stage, the detail and quality of which can vary substantially, the parties have arguably a limited access to each other's or third party's evidence prior to trial.

One last observation: the analysis of existing provisions reveals two significant flaws. Namely, procedure still suffers from lack of transparency ${ }^{62}$ and the judge still has no power to discipline disobedient parties during pretrial. Whereas preclusion stipulated in Articles $207 \S 6$ and $217 \S 2$ should be, in principle, a good incentive to provide information to the court, the sanction of losing the case on a procedural rule should be applied only after proper notice. Otherwise, I doubt whether the sanctioned party gets his or her day in court (fair trial). Moreover, these provisions are new and there is a lot of uncertainty about their actual scope of application. In any case, sanctions make sense only in a transparent environment. Given the above, I am somewhat sceptical about the use of these provisions as sanctions during pretrial 63 .

\footnotetext{
61 K. Weitz, P. Grzegorczyk, [in:] Ereciński (ed.), supra note 27, p. 989.

62 In Poland, there is hardly any transparency during proceedings, as far as the judge's mind is concerned. See B. Karolczyk, Rozważania o "braku zwtoki" jako podstawie uwzględnienia spóźnionego materiatu procesowego na gruncie 207 § 6 oraz 217 § 2 k.p.c. [Discussion of "Lack of Delay" as Grounds for Inclusion of Late Allegations and Evidence Pursuant to Art. $207 \S 6$ and 217 \& 2 of the Polish Code of Civil Procedure], Studia Prawnicze [Legal Studies] 2012, issue 1, pp. 141-142 and B. Karolczyk, Formułowanie twierdzeń pozwu oraz zasada da mihi factum dabo tibi ius w postępowaniu zwyczajnym w świetle nowelizacji KPC [Formulation of Allegations in the Complaint and the "Da Mihi Factum Dabo Tibi Ius" Principle in Ordinary Proceedings in the Light of Changes to the CCP], Monitor Prawniczy [Legal Monitor] 2013, issue 7, p. 348 et seq.

63 See also Karolczyk, Rozważania, supra note 62, pp. 145-146.
} 


\section{PRETRIAL IN OTHER EUROPEAN COUNTRIES}

\section{GERMANY}

It seems to me that pretrial is more comprehensive, coherent and flexible under the German $\mathrm{ZPO}^{64}$.

As a general rule, the dispute is to be dealt with and terminated at trial that has been comprehensively prepared 65 . It is the court's duty, not merely the right, to take steps necessary to prepare the trial in due time ${ }^{66}$. A case can be prepared through written (schriftliches Vorverfahren) or oral (früher erster Termin) means ${ }^{67}$. The choice is left to the judge, who will consider both the complexity and size of the case ${ }^{68}$.

An advance first hearing with the parties, their attorneys, a referendaire (judge's clerk), and sometimes even witnesses, can take place in a courtroom or the judge's chambers ${ }^{69}$. At the conference, having read the pleadings, the judge will orally present his understanding of the factual and legal issues in the case and discuss them with the parties ${ }^{70}$. He or she will also point out legal issues that the parties have missed or disregarded as irrelevant. It is the judge's duty to give hints to the parties and to share his or her observations (as the case proceeds) so that "procedural surprise" by the court can be avoided ${ }^{71}$. Thus, the parties are expected to act diligently and to allege facts, submit evidence, and put forward claims

64 See P. Gottwald, Civil Justice Reform: Access, Cost and Expedition. German Perspective, [in:] Zuckerman (ed.), supra note 5, p. 226 et seq.; P. Oberhammer, T. Domej, Germany, Switzerland and Austria: Powers of the Judge, [in:] Rhee (ed.), European Traditions in Civil Procedure, supra note 5, p. 115. See generally (in the Polish literature) Rylski, supra note 25, pp. 126-132 and Karolczyk, supra note 62, p. 129 et seq.

65 Cf. § 272(1) ZPO.

66 See $§ 272(2)$ and 273(1) ZPO.

67 See $§ 272(2)$ ZPO.

68 See P. L. Murray, R. Stürner, German Civil Justice, Durham, North Carolina: Carolina Academic Press 2004, p. 210; Leipold, supra note 6, pp. 65-66; Taruffo, supra note 4, p. 191.

69 See J. H. Langbein, The German Advantage in Civil Procedure, University of Chicago Law Review 1985, vol. 52, p. 828; Murray, Stürner, supra note 68, p. 227.

70 At the advance first hearing, the court shall set a deadline for submitting a written statement of defence should the defendant have not yet responded to the complaint at all, or not sufficiently. See § 275(3) ZPO.

71 See § 139(2) and 279(3) ZPO. This applies both to facts and evidence. See also D. Leipold, Kommentar zur § 139 ZPO, side note 57, [in:] Stein, Jonas, Kommentar zur Zivilprozessordnung, vol. 3, Tübingen: Mohr Siebeck 2006. 
in an efficient and complete manner. The judge will also set deadlines. The record of the hearing then serves as a "procedural map". It is also clear from the wording of $\S 275 \mathrm{ZPO}$ that the policy behind these provisions is to conclude cases without a subsequent main hearing ${ }^{72}$.

If additional written submissions are used for preparation, the proceedings naturally become more complicated and formalized, although it is arguably the preferred method for complicated matters due to efficiency concerns ${ }^{73}$. If for whatever reason neither the pleadings, nor the additional submissions have crystallized the factual framework of the dispute, the judge will address those deficiencies at the advance first hearing. Specifically, he or she will expect the parties to stipulate both contested and uncontested facts ${ }^{74}$.

This approach introduces transparency and facilitates the exchange of information. The ultimate goal is to render the proceedings as fair and diligent as possible ${ }^{75}$. Importantly, and unlike under Polish law, the court is authorized to rule on or to take evidence outside and ahead of trial ${ }^{76}$. Moreover, the court may base its decision on a claim, fact or provision of law omitted by a party or disregarded as procedurally irrelevant, only if it has been brought to the party's attention and sufficient time was

\footnotetext{
72 See § 275 ZPO ("Should the proceedings not be conclusively dealt with and terminated at the advance first hearing, the court shall issue all orders still required to prepare for the main hearing for oral argument").

73 See Taruffo, supra note 4, pp. 191-192. It is claimed that in practice written submissions are used more often. In such scenario, having received the complaint the defendant should notify the court within 2 weeks whether he or she will contest it. Otherwise, the court will give a default judgment. If notified, the court orders a deadline for the answer, not shorter than 2 weeks. See $\S 276$ ZPO. See also Leipold, supra note 6, p. 66.

${ }_{74}$ Murray, Stürner, supra note 68, p. 160.

75 See Leipold, supra note 71, side notes 1-3. This is one of the main functions of the judge in the context of his role to ensure efficiency. The doctrine writes about the duty of the judge to assist the parties so that the case can be decided according to the facts and the law. See Haas, The Relationship between the Judge and the Parties under German Law, [in:] Lipp, Fredriksen (eds.), supra note 5, pp. 95-96, 99 et seq; Langbein, supra note 69, p. 826; Langbein, supra note 9, p. 831; Murray, Stürner, supra note 68, pp. 166-177; Rylski, supra note 25, p. 128. Cf. R. Greger, [in:] R. Zöller, Zivilprozessordnung, Köln: Dr. Otto Schmidt 2004, p. 578 and L. Rosenberg, K. H. Schwab, P. Gottwald, Zivilprozessrecht, München: C. H. Beck 2004, p. 487.

76 See § 284 and § 358a ZPO. See Murray, Stürner, supra note 68, p. 228 et seq (more on German pretrial); Oberhammer, Domej, supra note 64, p. 115.
} 
provided for comments ${ }^{77}$. Furthermore, pursuant to $\S 273(2) 1 \mathrm{ZPO}$, in preparation for the trial the presiding judge may direct the parties to amend their pleadings or to provide further information, and may in particular set a deadline for explanations regarding certain items in need of clarification; otherwise the court may dismiss the complaint on the merits or disregard a defense as unfounded ${ }^{78}$. Finally, the court decides on the sequence in which factual or legal issues will be presented or argued 79 .

All of the above has to take place before the main oral hearing (trial).

The rights and duties of the court are interconnected with procedural burdens placed on the parties. According to $\S 282$ sec. 1 ZPO each party should submit procedural material in support of his or her claims, in particular allegations, defences, denials, evidence and arguments at a proper time in the proceedings. In addition, each party should be diligent in litigating the case, having due regard to the goal of concluding the proceedings as soon as possible ${ }^{80}$. Defences should be raised prior to the trial and at a time that allows the opposing party to react (§ 282(2) ZPO). Should a party fail to comply with these duties (e.g. ignore the deadlines, act with lack of diligence) the court may refuse to admit into

\footnotetext{
77 See § 139(2) ZPO. This provision applies accordingly when the court interprets the law or a fact in a different way from the one advanced by the party. The court will also draw the parties attention to the matters considered ex officio. See § 139(3) ZPO. See also Haas, supra note 75, pp. 95-96.

78 See R. Stürner, Die Richterliche Aufklärung im Zivilprozess, Tübingen: Mohr Siebeck 1982, pp. 50-52. However, the Federal Supreme Court has ruled that this duty does not apply to cases where both parties are represented by attorneys. See judgment of 2.10.1979, Neue Juristische Wochenschrift 1980, no. 33, p. 224; and of 9.11.1983, Neue Juristische Wochenschrift 1984, no. 37, p. 311. In the older literature one finds assertions that these provisions are in practice ignored by the judges. See Z. Deubner, Gedanken zur richterlichen Aufklarungs- und Hinweispflicht, [in:] Festschrift für Gerhard Schiedermair, München: C. H. Beck 1976, pp. 79, 88. Cf. however Haas, supra note 75, p. 102 and quoted jurisprudence (stating that the duty to hint and discuss does not depend on professional representation, which nonetheless affects its scope).

79 See $\S 136(3), \S 139, \S 272, \S 273$ ZPO. Thus, respecting the resources of the courts, questions of law essential to the existence of the dispute will be decided first, and disputed facts will only be established afterwards. See K. Schellhammer, Die Arbeitsmethode des Zivilrichters, Heidelberg: CF Müller 2002, p. 16 et seq. If the matter depends on a question of law, the judge will likely order the parties to submit observations in writing.

80 In this context, some commentators write about the burden to look after one's affairs and the burden to support the efficiency of the proceedings. See P. Willmann, Die Konzentrationsmaxime: eine Untersuchung heutigen und früheren Rechts, Berlin: Duncker \& Humblot 2004, p. 91.
} 
proceedings, as belated, any facts or evidence presented by such party at a later stage ${ }^{81}$.

Attorneys seem to play a crucial role - their participation is generally required in all courts except for the lowest level (district) courts

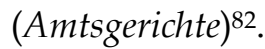

\section{NORWAY}

A similar system of judicial case management was introduced in Norway in $2005^{83}$. Pursuant to $\S 9-4$ sec. 1 the court is to actively and consistently manage the case so that that a fair resolution can be achieved swiftly and economically. The Dispute Act contains a lot of detailed provisions that exemplify this duty.

Basically, the judge must prepare a plan of the entire proceedings, which should result in a swift and fair resolution of the dispute ${ }^{84}$. Thus, once the answer has been submitted and parties have been heard in that regard, the court is to prepare such plan ${ }^{85}$. The trial should

81 See $\S 296$ ZPO. See also Karolczyk, Rozważania, supra note 62, pp. 132-133 and generally D. Leipold, Kommentar zur § 296 ZPO, side note 57, [in:] Stein, Jonas, supra note 71.

82 See $\S 78$ and $\S 271(2)$ ZPO. See Murray, Stürner, supra note 68, p. 161; K. Markiewicz, Zastęstwo procesowe $w$ świetle proponowanych zmian Kodeksu postępowania cywilnego [Procedural Representation in the Light of Proposed Changes to the Code of Civil Procedure], [in:] Markiewicz (ed.), supra note 60, p. 59; Langbein, supra note 69, p. 824. Cf. also § 1 of Bundesrechtsanwaltsordnung [Federal Law on Attorneys] of 1.08.1959 ("An attorney is an independent organ of the justice system").

83 However, commentators note a distinct lack of German influence on the new law. See H. H. Fredriksen, German Influence on the Development of Norwegian Civil Procedure Law, [in:] Lipp, Fredriksen (eds.), supra note 5, pp. 22-24. Instead, a clear common law trait is easily visible, for example, frequent use of judicial discretion.

In this section references are made to the Act of 17.06 .2005 no. 90 relating to mediation and procedure in civil disputes (The Dispute Act) [om mekling og rettergang i sivile tvister (tvisteloven)]. English unofficial translation can be found in Lipp, Fredriksen (eds.), supra note 5 , p. 164 et seq.

84 See $§ 11-6$.

85 See § 9-11. See also Becker, supra note 5, p. 57. This can be done through a teleconference. See § 9-4 sec. 3. The judge may decide against such hearing when it is clearly not needed. It has been said that such cases are not many. See H. J. Maeland, Recent Developments in the Relationship Between Judge and Parties in Norwegian Courts, [in:] Lipp, Fredriksen (eds.), supra note 5, p. 79 . 
commence not later than six months following the filing of the complaint ${ }^{86}$. On the other hand, pursuant to $\S 9-10 \mathrm{sec}$. 1 the pretrial should conclude two weeks before the start of the trial, at the latest, unless a different time has been set by the court. The Dispute Act provides for an open list of essential elements affecting pretrial, which should be considered by the court (§ 9-4 sec. 2). Generally, the goal is to crystallize both relevant facts and law ${ }^{87}$. Parties are entitled to comment on matters affecting procedural decisions (\$ 9-6 sec. 1$)^{88}$.

At the end of pretrial, in principle, the court will order the parties to submit their final written observations, that concisely summarize their respective prayers for relief, allegations, legal reasoning, as well as proposed evidence ( $\$ 9-10$ sec. 2 ). These need to be filed before the pretrial concludes and are in fact its last step. The court then explains to the parties how the trial will proceed 89 .

Consequently, once the pretrial has come to an end, new procedural material is precluded. Thus, if the opposite party objects, the other party may not submit new claims, broaden the prayer for relief in respect of a claim, submit new grounds upon which to base such prayer or present new evidence, unless this happens before the main hearing and is occasioned by the opposite party's closing speech or the court has granted leave ${ }^{90}$. The court will grant leave, if: a) the submitting party can be excused for not having submitted the new material earlier and it would be unreasonable to preclude it; b) the opposing party is sufficiently able to safeguard its interests following the amendments without the need for adjournment; or c) preclusion could lead to unreasonable loss for the submitting party (\$ 9-16 sec. 1 ). The court may allow the amendment under special conditions, even if prerequisites for leave are not met

\footnotetext{
86 Cf. Maeland, supra note 85, p. 82 (noting that in most cases the judge will fix the date of the main hearing 20-30 weeks ahead and this will take place at the conference following the receipt of the answer).

87 Interestingly, unlike most other European systems, Norwegian law requires the plaintiff to show legal basis for his prayer in the complaint. See § 9-2 sec. 2(d).

88 Pursuant to $\S 9-6$ sec. 2 a party shall raise any objection to procedural steps as soon as he or she is able to do so. Any objection raised at a later stage shall be precluded, unless the party was unaware of the basis for the objection and preclusion would be unreasonable.

89 See § 9-11 sec. 2. At trial, the judge is, again, clearly in charge. See § 9-13 sec. 2.

90 See $§ 6-16$ sec. 3 . See Maeland, supra note 85, p. 79.
} 
(see § 9-16 sec. 2). Nonetheless, even if the prerequisites for leave are met, the court may disallow the amendment if concern for progress of the case or another important consideration suggests so. Refusal must not, however, be unreasonable (§ 9-16 sec. 3). In addition, if timeframes for submissions or presentation of evidence have been agreed or imposed, the court shall ensure that these are observed and may preclude belated material, if necessary (§ 9-13 sec. 2).

\section{LITHUANIA}

The Lithuanian Code of Civil Procedure of $2002^{91}$ contains a lot of inspiring and progressive solutions in the area of pretrial, which the Code expressly recognizes as an important stage in civil proceedings. Similarly to German and Norwegian law, the court is authorized to decide on the manner in which the trial will be prepared, considering the circumstances of the case (e.g. willingness to settle or type of representation) ${ }^{92}$. Importantly, the court can order appearance at the pretrial hearing, as well as give default judgment in case one party fails to appear without an advanced, reasoned notice ${ }^{93}$.

At the end of pretrial the court directs the case for trial, a decision somewhat similar to an old Germanic order ${ }^{94}$. As a result the case is "locked". In principle, therefore, no amendments can be introduced, unless such need arose afterwards and the other party does not object or the court grants leave, believing this will not delay the disposition of the case ${ }^{95}$.

91 Civil Procedure Code of 28.02.2002, Law No. IX-743 (last amended on 23.09.2010, by Law No. XI-1032).

92 See V. Nekrošius, supra note 33, p. 63.

93 Ibid., p. 63. Dutch research suggests that ordering personal appearance at the pretrial hearing scheduled after the submission on an answer significantly reduces the time of the proceedings. See Verkerk, supra note 5, p. 65.

94 Beweisinterlokut or Beweisurtheil was a court's order issued every time the proceedings moved to a next stage (and there were likely to be at least three). In it, the court would identify material facts subject to proof, decide who would have the burden of proof with regard to specific allegations, as well as set deadlines for submission of evidence. Matters not included in the order would become precluded. See A. Engelmann (translated and edited by R. W. Millar), History of Continental Civil Procedure, Boston: Little, Brown \& Co. 1927, pp. 553-555.

95 Nekrošius, supra note 33, pp. 68-69. Moreover, once the order has been issued, a party is precluded from filing a counterclaim. 


\section{PRETRIAL IN FEDERAL COURTS: INTRODUCTION}

Federal civil litigation, governed by the Federal Rules of Civil Procedure of 1938 ("FRCP"), is clearly divided into trial and pretrial. From the procedural perspective, the pretrial stage can be divided further into three sub-stages:

1) the pleading stage, where the goal is to set the outer limits of factual and legal issues in the case, as well as to identify key disputed facts, if any, by cumulating allegations and prayers for relief submitted by the parties; the first phase of this phase is called "motion practice", whereby the defendant submits procedural objections and defenses through written motions prior to appearance (i.e. plea regarding the merits),

2) preparatory (organizational) stage, which begins once the pleading stage has concluded, and is about organizing and planning out the reminder of the pretrial, especially discovery, and

3) discovery, which is based on the mutual duty (first automatic and then on demand) to disclose potential procedural material relevant to allegations and defences already submitted by the parties ${ }^{96}$.

In practice, the division into pretrial and trial has resulted in a shift of focus from the latter to the former. The ultimate outcome is fewer trials. This is apparently consistent with the assumptions made by the drafters of the FRCP. However, for significant reasons that cannot be discussed here, this situation is criticized.

Pretrial conference and discovery are separate, but heavily interrelated institutions that often overlap. Both are considered essential in achieving the goal of swift and fair resolution of civil disputes, as well as nullifying the practice of "procedural ambush" by the opponent ${ }^{97}$.

\footnotetext{
96 Discovery is an extensive topic beyond the scope of this article. See Rule 26 FRCP. In Polish literature see Karolczyk, supra note 12, pp. 481-506.

97 See Rule 1 FRCP (the purpose of FRCP). See also e.g. Clark v. Pennsylvania R. Co., 328 F.2d 591, at 594 (2nd Cir. 1964):

In the heyday of Common Law Pleading, when each of the numerous technicalities involved provided the members of the bench and bar with a source of continual intellectual amusement and pleasure, the sporting theory of justice prevailed. To win a lawsuit by guile and surprise or by the skillful manipulation of mysterious rules, understood only by the elite, was quite the thing to do. The development of pretrial
} 
Neither discovery, nor pretrial conference (hearing) was known in common law. The first laws of this kind, aimed at reducing delay in trial courts, began to appear at a state level ${ }^{98}$ between the 1920's and 1930's.

Thus, from today's perspective the system of judicial case management introduced at the federal level in 1938 was incomplete. In a way, its subsequent development of this technique was a natural consequence of the federal lawmaker's acceptance of the liberal standards of notice-pleading, joinder of parties and claims, as well as discovery 99. Furthermore, since the pretrial fact-finding was placed within the adversarial framework, namely in the hands of the parties (faced with incentives to abuse their procedural rights), it became obvious pretty quickly that an active judge is absolutely necessary to prevent chaos ${ }^{100}$.

Rule 16 (titled "Pretrial Conferences; Scheduling; Management") is there to help manage the period between the end of the pleading stage and the start of the trial. Thus, a pretrial hearing (conference) was intended by the drafters to be a meeting between the judge and the attorneys dedicated to discussing the preparation of the trial and the settlement of the case ${ }^{101}$. In other words, the function of Rule 16 was to simplify, shorten and reduce the cost of the proceedings, especially the trial ${ }^{102}$.

procedure and the formulation of Rule 16 of the Federal Rules of Civil Procedure, and similar provisions in most if not all of the States, represents one of the great Twentieth Century contributions to the improvement of judicial administration and the furtherance of effective, timely justice. One of the prime objectives of this new, but now firmly established procedural device, is to do away with the old sporting theory of justice and substitute a more enlightened policy of putting the cards on the table, so to speak, and keeping surprise tactics down to a minimum.

98 For more details see C. Wright, A. Miller, M. Kane, Federal Practice and Procedure, Civil 2d, vol. 6A, St. Paul, Minnesota: West Group $1990 \S 1521$, pp. 214-216 and Note, Variance from the Pretrial Order, The Yale Law Journal 1951, issue 60, p. 175. See also Advisory Comittee's Notes to Rule 16 (1937) sec. 1; http://www.law.cornell.edu/rules/frcp/rule_16 (quite surprisingly, noting that inspiration for Rule 16 was also found in 19th century English law) [last accessed: 27.04.2013]. For a summary of non-legal considerations that led to the rise of this doctrine, in Polish literature, see Karolczyk, supra note 12, pp. 106-108.

99 See J. Friedenthal, M. Kane, A. Miller, Civil Procedure, St. Paul, Minnesota: West Group 1999, p. 442.

100 See Leipold, supra note 6, p. 68.

101 See Advisory Committee's Notes to 1983 Amendments to Rule 16; http://www.law.cornell.edu/rules/frcp/rule_16 [last accessed: 27.04.2013]. It is still debated, which of these goals should have priority.

102 Note, supra note 98 , p. 175. In theory, the exchange of information during discovery would render the trial redundant. 
Over time, however, the Rule became much more. It became the starting point for extending judicial supervision over the entire pretrial, crystallizing the judge's role as settlement promoter, and the main tool to effectively plan, coordinate, and carry out discovery. According to the leading commentary to $\mathrm{FRCP}$, the main goal of pretrial is the assertion of judicial control over the case ${ }^{103}$. Thus, as noted by J. Resnik, over the years following the introduction of FRCP the judges have consciously changed their roles from those of a (passive) adjudicator to an active manager (and then, according to that author, to a settler) ${ }^{104}$.

Even though empirical data regarding the practical effects of Rule 16 FRCP collected in the mid-20 th century is ambiguous ${ }^{105}$, it has been confirmed that it serves four legitimate goals. First, it enhances the preparation of procedural material for presentation at trial. Second, it eliminates unfair procedural tactics by the parties (ambush). Third, it increases the likelihood of settlement. Fourth, it improves the overall fairness and transparency of the proceedings ${ }^{106}$.

Importantly, federal judges are trained, usually after appointment, in pretrial techniques. However, since many of them have been practicing

103 See C. Wright, M. Kane, Federal Practice and Procedure: Federal Practice Deskbook, vol. 20, St. Paul, Minnesota: West Group 2002, § 97, pp. 872-873; Advisory Committee's Notes to 1983 Amendments to Rule 16, supra note 101.

${ }^{104}$ J. Resnik, Failing Faith: Adjudicatory Procedure in Decline, University of Chicago Law Review 1986, issue 53, p. 529. See also J. B. Oakley, V. D. Amar, American Civil Procedure: A Guide to Civil Adjudication in US Courts, Haga: Wolters Kluwer 2009, p. 27; Langbein, supra note 69 , p. 858 et seq. See also Resnik, supra note 8, p. 374. J. Resnik uses the term "managerial judging" to describe two trends: 1) the increased involvement of the judge with the pretrial fact-finding process, and 2) the increased activity and responsibility of the judges in the area of creating mechanisms allowing for enforcement of judicial decisions in public or private litigation. One of the reasons for this was the rapid growth of class action cases based on mass tort and product liability claims. It forced a change in how cases were prepared for filing, settled, prepared for trial or, ultimately, tried. Cf. Ch. Chayes, The Role of the Judge in Public Law Litigation, Harvard Law Review 1976, issue 89, p. 1281.

105 See Friedenthal, supra note 99, p. 444 and sources cited there.

106 See M. Rosenberg, The Pretrial Conference and Effective Justice, New York: Columbia University Press 1964, p. 29. Pretrial conference may take place prior to discovery, during discovery as well as upon its conclusion or close to trial, which creates settlement opportunities and makes it possible to limit the disputed facts, should the case proceed to trial. See also Judicial Conference of the U.S., The Civil Justice Reform Act of 1990: Final Report, Washington 1997, p. 10 (finding that "(..) managed cases will settle earlier and more efficiently, and will provide a greater sense of justice to all participants. Even in the absence of settlement, the result will be a more focused trial, increased jury comprehension, and a more efficient and efficacious use of our scarcest institutional resource, judge time"). 
lawyers, they are already quite familiar with them. Moreover, regardless of the FRCP and detailed local court rules, the Judicial Conference of the United States (Committee on Court Administration and Case Management) has prepared and published Civil Litigation Management Manual for use as guidance by judges, presenting "both successful practices and suggested practices in the light of the new civil litigation landscape"107.

In the pages that follow I examine the structure of pretrial and, within it, the relationship between the judge and the parties.

\section{JUDICIAL CASE MANAGEMENT IN FEDERAL COURTS AT THE PRETRIAL STAGE}

\section{PRETRIAL CONFERENCE}

In any civil action the court may order the attorneys and any unrepresented parties to attend one or more pretrial conferences ${ }^{108}$. In order words, the court is not bound to schedule one and the decision in that regard is left to the judge's discretion ${ }^{109}$. In practice, the number of meetings of course varies depending on the size or complexity of the case $\mathrm{e}^{110}$.

The purpose of the pretrial conference may be, by way of example, to establish early and continuing control so that the case will not be protracted because of lack of management, improving the quality

\footnotetext{
107 Judicial Conference of the U.S., Civil Litigation Management Manual, Second Edition 2010. Available at http://www.uscourts.gov/FederalCourts/PublicationsAndReports/CivilLitig ationManagmentManual.aspx [last accessed: 27.04.2013].

108 See Rule 16(a) FRCP.

109 This rule may be different under local rules. Local rules of procedure are detailed codes of procedure in a given district. For example, see Local Rules of Practice in Civil Proceedings before the United States District Court for the Northern District of California ("Civil Local Rules"), available at http://www.cand.uscourts.gov/localrules [last accessed: 27.04.2013]. Moreover, the manner of the conference also depends on the judge. Sometimes it may be a rather formal meeting, in the trial room, officially recorded; at other times it may be a meeting in the judge's chambers and the only official "record" is the ultimate order. See Wright, Kane, supra note 103, §97, p. 876.

110 Cf. Federal Judicial Center, Manual for Complex Litigation, Third, 1995, § 21.2, p. 40 et seq., Manual for Complex Litigation, Forth, 2010, p. 31 et seq. ( $\$ 11$ Pretrial procedures).
} 
of the trial through more thorough preparation and facilitating settlement (Rule 16(a)). In practice, the judges are encouraged to utilize Rule 16 as early as practicable, especially in order to: 1) handle discovery related issues, 2) decide whether any motions for summary judgment ${ }^{111}$ should be made, and 3) discuss settlement ${ }^{112}$. As discovery advances, the last two items seem to grow in importance due to increased volume of exchanged information, which in turn allows for a more accurate assessment of the case by both sides.

Under Rule 16(c)(1), a represented party must authorize at least one of its attorneys to make stipulations and admissions about all matters that can reasonably be anticipated for discussion at a pretrial conference. Furthermore, if appropriate, the court may require that a party or its representative be present or reasonably available by other means to consider possible settlement.

In addition, the court may order the parties to submit in advance legal memoranda regarding matters to be considered or acted upon at the conference. The Rule provides for a catalogue of such matters. Given the scope and theme of this paper, the most relevant are:

1) formulating and simplifying the issues, and eliminating frivolous claims or defenses,

2) amending the pleadings, if necessary or desirable,

3) obtaining admissions and stipulations about facts and documents to avoid unnecessary proof (e.g. authentication) or cumulative evidence, limit the use of expert witness testimony, and rule in advance on the admissibility of evidence ${ }^{113}$,

\footnotetext{
111 See Rule 56 FRCP(a) ("A party may move for summary judgment, identifying each claim or defense - or the part of each claim or defense - on which summary judgment is sought. The court shall grant summary judgment if the movant shows that there is no genuine dispute as to any material fact and the movant is entitled to judgment as a matter of law. The court should state on the record the reasons for granting or denying the motion"). The key part is "no genuine dispute as to any material fact".

112 G. C. Hazard, Jr. et al, Pleading \& Procedure State and Federal Cases and Materials, New York: Foundation Press 2009, p. 1061.

113 For a more detailed presentation (in Polish literature) of issues pertaining to admissibility of evidence in American law in context of unlawful evidence see B. Karolczyk, Dopuszczalność "dowodów uzyskanych z naruszeniem prawa" w postępowaniu cywilnym [Admissibility of "Unlawful Evidence" in Civil Litigation], Przegląd Sądowy [Judicial Review] 2012, issue 4, p. 100 et seq.
} 
4) identifying witnesses and documents, scheduling the filing and exchange of any pretrial briefs, and setting dates for further conferences and for trial,

5) referring matters to a magistrate judge, or a master ${ }^{114}$,

6) determining the form and content of the pretrial order,

7) adopting special procedures for managing potentially difficult or protracted actions that may involve complex issues, multiple parties, difficult legal questions, or unusual proof problems,

8) ordering the presentation of evidence early in the trial on a manageable issue that might, on the evidence, be the basis for a judgment as a matter of law under or a judgment on partial findings,

9) facilitating in other ways the just, speedy, and inexpensive disposition of the action ${ }^{115}$.

Pursuant to Rule 16(d) each decision or action taken shall be reflected in an order issued by the court. This order is controlling unless the court modifies it, which may happen, usually on a party's motion to amend.

Given the problem of 'shotgun pleadings' the jurisprudence of appellate courts recognizes the importance of judicial case management, especially pretrial orders. In Morro v. City of Birmingham ${ }^{116}$ the Court of Appeals for the 11th Circuit said that the problem was "ubiquitous". Moreover, the Court noted:

"Given the seriousness of that problem, it is "particularly important for district courts to undertake the difficult, but essential, task of attempting to narrow and define the issues» before trial. Critical to proper discharge of that duty is effective use of pretrial orders, which in turn requires that such orders be firmly (but fairly) enforced. We have not hesitated to back up district courts when they put steel

\footnotetext{
114 These two officials help the judge with managing the case. Usually their decisions can be challenged before the judge, who either confirms the decision or rules upon the matter himself or herself. Furthermore, certain findings made by these officials, if left uncontested, may be used at trial. See Rule 53(e).

115 See Rule 16(c)(2). See also Friedenthal, supra note 99, pp. 446-447.

116117 F.3d 508, 515 (11 th Cir. 1997).
} 
behind the terms of pretrial orders and hold parties to them"117 (internal citations omitted).

Although this relates to discovery, which is outside the scope of this paper, I would also like to hint at Rule 26(a)(3). This Rule provides for mandatory Pretrial Disclosure to the opposing party of specific information relating to evidence, which the party intends to or may potentially present at trial118. Unless the court orders otherwise, these disclosures must be made at least 30 days before trial. Within 14 days after they are made, a party may serve upon the opponent and promptly file with the court a list of objections - Rule 26(a)(3)B. Any objection not so made - except for two under Federal Rules of Evidence - is deemed waived, unless excused by the court for good cause.

\section{PRETRIAL SCHEDULE}

Whereas the decision to hold a pretrial conference is left to the discretion of the judge, he or she is bound under the Rules to issue a scheduling order. A scheduling order is basically a comprehensive case management plan at the pretrial stage. It details actions which the parties wish or may take prior to trial, essential factual and legal elements of the dispute, as well as deadlines for specific actions ${ }^{119}$.

The judge issues the order after consulting with the parties' attorneys and any unrepresented parties at a scheduling conference or by telephone, mail, or other means ${ }^{120}$. If no conference was held, 14 days prior

\footnotetext{
117 Ibid., quoting Ebrahimi v. City of Huntsville Bd. of Educ., 114 F.3d 162, 168 (11th Cir.1997) and subsequently citing Hodges v. United States, 597 F.2d 1014, 1017 (5th Cir.1979).

118 This includes detailed information regarding witnesses and documents. See Rule 26(a)(3) for details.

119 See Rule 16(b)(3)(A) ("The scheduling order must limit the time to join other parties, amend the pleadings, complete discovery, and file motions"). The order may also address a myriad of other matters, including dates for pretrial conferences and for trial, as well as "other appropriate matters". See Rule 16(b)(3)(B).

120 See Rule 16(b)(1). In case the conference was held, Rule 16(d) applies. An example can be found at http://www.nynd.uscourtp.gov/documents/CivilCaseMgmtPlan FILLABLE_000.pdf [last accessed: 27.04.2013].
} 
to the deadline FRCP set for the judge to act ${ }^{121}$, at the latest, the parties may submit a written report regarding anticipated discovery. The judge will consider these reports while drafting the scheduling order.

The order controls the subsequent course of action (during pretrial). It may be modified only for good cause (Rule 16(b)(4)). Again, given the language of the Rule, we see that American judges enjoy broad discretionary powers at the pretrial stage ${ }^{122}$.

\section{SANCTIONS FOR LACK OF OR IMPROPER PARTICIPATION IN THE PRETRIAL}

All the essential duties of the parties, namely participation of properly authorized attorneys in the conference and compliance with the court's orders, are sanctioned, if disregarded.

Thus, pursuant to Rule 16(f)(1), on a motion by the other party or on its own, the court may issue any just orders ${ }^{123}$, if a party or its attorney: (a) fails to appear at a scheduling or other pretrial conference, (b) is substantially unprepared to participate - or does not participate in good faith - in the conference, or (c) fails to obey a scheduling or other pretrial order.

The goal of these orders is to sanction (penalize) an attorney or a party for acts or omissions that delay or obstruct the proceedings ${ }^{124}$. Without the diligent participation of counsel neither will the pretrial achieve its goals, nor will the trial plan be created (see below). Therefore, proper

\footnotetext{
121 The judge must issue the scheduling order as soon as practicable, but in any event within the earlier of 120 days after any defendant has been served with the complaint or 90 days after any defendant has appeared. Rule 16(b)(2).

122 It has been noted on many occasions that this may lead to abuse, especially since the exercise of discretion at the pretrial stage is very often informal and is excluded from appellate review. See, for example, Resnik, supra note 8, pp. 380, 424 et seq.

${ }_{123}$ These orders may include an order: 1) prohibiting the disobedient party from supporting or opposing designated claims or defences, or from introducing designated matters in evidence, 2) striking pleadings in whole or in part; 3) staying further proceedings until the order is obeyed, 3) dismissing the action or proceeding in whole or in part, 4) rendering a default judgment against the disobedient party, or 5) treating as contempt of court the failure to obey any order except an order to submit to a physical or mental examination. 124 See Goforth v. Owens, 766 F.2d 1533 (11 th Cir. 1985).
} 
participation is absolutely necessary for the success of the pretrial and, in turn, the swift and fair resolution of civil disputes ${ }^{125}$.

The core component of federal codification, namely judicial discretion, is visible yet again. The form of sanction is applied in a discretionary manner, depending on the circumstances of the case, proportionally to the gravity of transgression and its impact on the opposing party. As authorized by Rule 16(f)(1), in extreme scenarios the case may even be dismissed ${ }^{126}$. Moreover, instead of or in addition to any other sanction, the court must order the party, its attorney, or both to pay reasonable expenses - including attorney's fees ${ }^{127}$ - incurred because of any noncompliance with Rule 16, unless it was substantially justified or other circumstances make an award of expenses unjust (Rule 16(f)(2)).

\section{TRIAL PLAN}

The court may hold a final pretrial conference as close to the start of trial as is reasonable. The purpose of this meeting is to formulate a trial plan, including a plan to facilitate the admission of evidence. Therefore, final pretrial conference must be attended by at least one attorney who will conduct the trial for each party and by any unrepresented party ${ }^{128}$.

Under local rules attorneys are often required to submit - jointly or individually and in advance of the final pretrial conference - final pretrial brief(s) ${ }^{129}$. Such brief(s) should summarize the pretrial stage and coherently present the party's perspective on the structure of the trial, especially the presentation of evidence. It should include: 1) a list of facts

\footnotetext{
125 See Note, supra note 94, p. 179; Tucker v. District of Columbia, 115 F.R.D. 493 (D.D.C. 1987). 126 See, e.g., Wirtz v. Hooper-Holmes Bureau, Inc., 327 F.2d 939 (5th Cir. 1964); Callip v. Harris County Child Welfare Dept., 757 F.2d 1513 (5 $5^{\text {th }}$ Cir. 1985); Sheppard v. Glock, Inc., 176 F.R.D. 471 (E.D. Pa. 1997), judgment aff'd, 142 F.3d 429 (3rd Cir. 1998).

${ }^{127}$ Fees are basically actual fees. See Laffey Matrix at http://www.justice.gov/usao/dc/divisions/civil_Laffey_Matrix_2003-2012.pdf [last accessed: 27.04.2013]. The matrix is commonly used by federal courts to calculate reasonable attorney's fees. By way of example, an hour of time of an attorney with 10 years of experience costs 350 USD. The matrix is not used when maximum hourly rate is set by statue (e.g. in cases against federal government it is simply 125 USD per hour). Notably, this is an exception to the so called American rule (i.e. each party pays its own costs).

128 See Rule 16(e).

129 Templates are usually used. See, e.g. http://www.txp.uscourtp.gov/district/judges/ghm /jointptorder.pdf [last accessed: 27.04.2013].
} 
and points of law that are either contested or stipulated, and indicating those that the party will try to prove or argue at trial, 2) a list of witnesses and tangible evidence (exhibits), 3) possible legal issues with evidence that the court should rule on prior to trial and other motions in limine, 4) possible amendments to the pleadings given the outcome of discovery, and 5) a summary of settlement discussions ${ }^{130}$.

These briefs carry great significance. They are discussed at the final pretrial conference. As already said, jurisprudence recognizes both the role of counsel and the weight of the pretrial. Thus, the litigant's duty to articulate, in writing and prior to trial, all objections to the opponent's position helps the judge considerably in understanding the case and preparing for trial ${ }^{131}$. The claims, issues, and evidence are laid down in the final pretrial order, thereby narrowing the trial and expediting the proceeding 132 .

Following the final pretrial conference, the court issues the final pretrial order ${ }^{133}$. The manner in which the trial plan is actually prepared varies as this decision is within the judge's discretion. In practice, especially in class actions, the judge will expect the plaintiff's attorney to submit a draft of the order, which will then be verified or amended. Another popular practice is joint preparation by the trial attorneys. Should they fail to agree on the draft, it will be prepared by the (now probably annoyed) judge ${ }^{134}$. The judge may require the attorneys to sign the trial plan, which is quite often the case.

Since it draws on the information presented in the final pretrial briefs, the final pretrial order is structured in a similar fashion. It is a comprehensive case management plan for the trial stage. It contains attorneys' identification and contact information, the trial schedule, including the number of days or hours, a list of contested and stipulated

\footnotetext{
${ }^{130}$ Cf. e.g. Rule 16-9 Civil Local Rules. Such briefs should not be used to introduce any new matter into the proceedings.

131 See Lexington Inp. Co. v. Cooke's Seafood, 835 F.2d 1364, 1368 (11 th Cir. 1988).

132 Cf. Elvis Presley Enterp. v. Capece, 141 F.3d 188, 206 (5 ${ }^{\text {th }}$ Cir. 1998), citing Flannery v. Carroll, 676 F.2d 126, 129 (5th Cir. 1982).

133 This document is also sometimes referred to as "trial plan" or "(final) joint pretrial order". 134 See Friedenthal, supra note 99, p. 449.
} 
issues of fact and law, identification and sequence of evidence as well as a list of exhibits ${ }^{135}$, etc.

Pursuant to Rules 16(e) and 16(c) FRCP the order controls the course and scope of subsequent proceedings. Importantly, it supersedes all pleadings, including claims raised therein, and governs the issues and evidence that will be presented at trial ${ }^{136}$. As a result, allegations (facts), defenses, objections, and evidence omitted from the trial plan will be excluded from the trial. This is a rigid rule, but a consequence of the fair goal that pretrial needs to be effective. The court may modify such order, however only to prevent manifest injustice ${ }^{137}$.

\section{CONCLUSIONS}

\section{GENERAL}

This limited inquiry into pretrial regulations reveals three significant recurring themes.

First, and this has already been noted before ${ }^{138}$, we can see a clear trend in European systems to distinguish and regulate the pretrial part of civil

\footnotetext{
${ }^{135}$ Cf. ibid., p. 449. An example of a comprehensive trial plan in a complex case can be found here: http://www.shellnewp.net/ShellAfrica/Doc\%20369\%201\%20to\%2046.pdf [last accessed: 27.04.2013].

${ }^{136}$ Hazard, supra note 112, p. 1061. See Erff v. Markhon Industries, Inc., 781 F.2d 613 (7th Cir. 1986), p. 617; Elvis Presley Enterp. v. Capece, at 206 citing McGehee v. Certainteed Corp., 101 F.3d 1078 (5 ${ }^{\text {th }}$ Cir. 1996), p. 1080 (citing Branch-Hines v. Hebert, 939 F.2d 1311, 1319 (5 $5^{\text {th }}$ Cir. 1991)), where the Court said: "It is a well-settled rule that a joint pretrial order signed by both parties supersedes all pleadings and governs the issues and evidence to be presented at trial". See Elvis Presley Enterp. v. Capece, at 206 (citing Valley Ranch Dev. Co. v. FDIC, 960 F.2d 550, 554 (5 ${ }^{\text {th }}$ Cir. 1992)), ("Once the pretrial order is entered, it controls the course and scope of the proceedings under Federal Rule of Civil Procedure 16(e), and if a claim or issue is omitted from the order, it is waived, even if it appeared in the complaint"). See also L. H. Dietz, Pretrial Conference and Procedure $\S 63$ and cited sources, [in:] American Jurisprudence, Second Edition, West Group 2011.

137 See Rule 16(e). See also decisions discussed by L. H. Dietz, supra note 136, § 74 \& § 78.

138 This has already been noted. See e.g. R. Stürner, [in:] The American Law Institute/UNIDROIT, Principles of Transnational Civil Procedure, New York 2006, p. 6 and Principle 9 (division of proceedings into three stages: pleading (initial), interim and final (trial)). The text of Principles with commentary is also available at http://www.unidroit.org/english/principles/civilprocedure/ali-unidroitprinciples-e.pdf [last accessed: 27.04 .2013 ].
} 
litigation. Currently, there seems to be a growing consensus about its significance, particularly since the social model of procedure does not provide for American-style discovery. The difference brings its own challenges to European-style litigation. Regardless of the different position of the judge and the intensity of judicial case management, other methods of eliminating information asymmetry ahead of trial are needed. Moreover, the distinct purpose and flavor of pretrial, which are, however, intimately related to adjudication of the case, seem to be gaining recognition. Therefore, a proliferation of rules creating or modifying pretrial regulations comes as no surprise. Accordingly, also in Poland, we will very likely see continued development of pretrial provisions. Some ideas have already been copied by the Polish lawmaker; however, this piecemeal approach to legislation is bad. I will discuss this thesis in a greater detail below.

Second, the concept of pretrial is, logically, an element of an even bigger concept, and that is judicial case management. As noted at the beginning of this paper, at least since the late 90's this technique has been heralded in Europe as one of the main tools to increase the efficiency of civil justice systems. Academics and lawmakers alike have directed their special attention to it.

What is important in the light of this short comparative study from the Polish perspective, is that there can be no judicial case management, and therefore no pretrial, without judicial discretion. This is another vital leitmotif in its own right that awaits research. Here, however, I just want to put forward thesis no. 2: owing to the history of the state and the law in Poland, judicial discretion in civil procedure is problematic. I will get to that in a moment and will link this with the earlier thesis no. 1.

A third important conclusion is that judicial case management comes at a cost of trimming the contours of the adversary system in its traditional, $19^{\text {th }}$ century, meaning. It underscored a party as dominus litis (master of the suit). To me, that understanding of the system, which was incorporated into the Napoleon Code of Civil Procedure (1806) or the original text of the German ZPO (1877) was a natural consequence of the fall of the ancien regime and "a radical break with" its form of procedure 
(sometimes referred to as ius commune) ${ }^{139}$. These laws, and many others, including the organization of legal professions, were created and addressed to the new, growing class of liberal, "aspiring bourgeoisie"140.

On the Continent, the first lawmaker that started trimming that "fat" was Franz Klein, who was a vigorous opponent of the adversary system ${ }^{141}$. It is common knowledge among procedure scholars that it was Klein who introduced the "active" judge into Austrian ZPO (1895)142.

Why is this historical background even relevant?

\section{Conclusions With ReGard to Polish LAW}

Well, mostly because the Polish Code of Civil Procedure of 1930 was heavily influenced by the Austrian (social) model. The existing CCP, in turn, was based on the Code of 1930. In the meantime (1945-1964), however, under Soviet influence, the social model was gradually turned into the socialist model. As a result, several key concepts were taken to the next level, so to speak ${ }^{143}$. Why is that relevant? Two reasons.

\footnotetext{
139 See M. Cappelletti, Social and Political Aspects of Civil Procedure: Reforms and Trends in Western and Eastern Europe, Michigan Law Review 1971, vol. 69, no. 5, pp. 853-854. For a good historical discussion of ius commune and its rather complex meaning see C. H. van Rhee, Towards a Procedural Ius Commune? [in:] J. Smits, G. Lubbe (eds.), Remedies in Zuid-Afrika en Europa, Antwerp: Intersentia 2003, pp. 217-232.

140 See Ch. Althammer, Foreign influences on German Reforms of Civil Procedure, [in:] Lipp, Fredriksen (eds.), supra note 5, p. 30. See also C. H. van Rhee, The Development of Civil Procedural Law in Twentieth Century Europe: From Party Autonomy to Judicial Case Management and Efficiency, [in:] Rhee, Judicial Case Management, supra note 5, p. 12

141 Throughout the $19^{\text {th }}$ century the principle dominated in European procedural system, with the exception of Prussia (Allgemeine Gerichtsordnung 1781-1846). F. Klein opposed its use. He believed it rendered the system susceptible to abuse which in turn ultimately defeated its goals. See F. Klein, Pro future: Betrachtungen über Probleme der Civilprocessreform in Österreich, Leipzig, Vienna: Franz Deuticke 1891, pp. 19, 36, 41; Rhee, supra note 140, p. 13. 142 See Cappelletti, supra note 139, p. 854; Rhee, supra note 140, p. 12 and source citied there. Klein did it, however, for slightly different reasons from those of the Americans almost 40 years later. Additionally, he felt strongly against judicial discretion.

143 The prime examples are CCP Articles 3 § 2, 6, 7, 213 and 232 in their original wording. See supra note 22. The effect of these provisions was basically to put all the burdens on the court so that it would "determine the truth". Doctrinally and practically, the judge was expected to handle everything on his or her own "in the quiet surroundings of his or her office". This meant that passiveness of the parties had reached an unprecedented level. Cf. Galič, supra note 16, pp. 96-97 (noting inactivity, incompetence, and lack of diligence as patterns in private law practice under the socialist procedure of Yugoslavia). Cf. also Uzelac, supra
} 
They also explain why considerable barriers to the continued development of pretrial provisions exist in Poland.

First, because the structure of the CCP was designed under the socialist regime, from the modern perspective it is simply ancient and thus inadequate in the existing socio-economic conditions ${ }^{144}$. The parties' limited access to information prior to trial and the unchanged structure of proceedings since the early 60 's mean that trial preparation is still almost exclusively the responsibility of a judge. Moreover, all this is done without a written document that outlines the course of the proceedings and is disclosed to all participants. This is one of the ways in which an astonishing lack of transparency in Polish civil justice system manifests itself. The judge does not share his thoughts with the parties, does not consult, does not discuss; instead he or she often allows them to act as they please, especially as far as presentation of evidence is concerned. In a sense, ironically, it's the archetype of an old common law passive arbiter. This has to change.

Second, given the experience of the socialist era, the proposition to limit the adversarial elements in order to increase efficiency through the use of judicial case management based on judicial discretion is treated with great reserve ${ }^{145}$. There are many reasons for that.

Actually, many people would love to see the "classic" adversary system expand. No wonder! We never had it in the first place, and now you expect us to simply move forward? It is also very convenient for attorneys to make this argument since rules of professional conduct are also ancient. Another one would be that judges are young and have not been trained

note 16, p. 388 (arguing that the instrumentalist approach of the socialist legal world "was, by its nature, not socialist").

144 The inadequacy of the model is beautifully exemplified by the "massive inefficiency: court backlogs and judicial delays [that] started to accumulate throughout the countries of the former Socialist bloc". See Uzelac, supra note 16, p. 388.

145 See e.g. S. Cieślak, Koncentracja materiatu procesowego po nowelizacji kodeksu postępowania cywilnego z 16 września 2011 r. [Concentration of Procedural Material After Amendments to the Code of Civil Procedure from 16 September 2011], Palestra [The Bar] 2012, issue 9-10, p. 22 (critique of "very general" formulation of the provision allowing the court, as an exception to the rule of preclusion, to admit late procedural material under "other exceptional circumstances", which may "lead to erroneous «arbitrary» judicial decisions"). Cf. Galič, supra note 16, pp. 83-84 (noting that in Slovenia procedural rules based on general principles and legal standards are "often rejected with aversion as being «unclear», «too vague» (...), therefore open to abuse and arbitrary decision-making"). 
to use discretion, despite the changes in the law. The established legal culture is "legalist" and the respect for courts is low, especially among attorneys. In addition, arguably, trial courts do not enjoy broad deference from appellate courts. Thus, the lack of different standards of appellate review is a significant procedural problem. These exist in the US and are developing in the jurisprudence of the ECJ. As a result, the existing system of full de novo appellate review will likely have a detrimental influence on whatever pretrial practice will have developed. On top of that, judicial management is perceived as perversely closed to the socialist model (which nobody seems to miss? $)^{146}$. This is clearly not the case. Judicial case management and an active judge are there to facilitate the exercise of the constitutional right to court, increase transparency, and speed up the proceedings. There is no conflict between this and the principle of the adversary system or the dispositive nature of civil litigation ${ }^{147}$. The ultimate practical outcome of these concepts is obviously "dependant on the good will and skills of the judge"148.

This leads me to thesis no. 3: Continued changes of the existing Code will be ineffective since new coherent, modern codification is urgently needed ${ }^{149}$. Otherwise, the existing habits and practice 150 will override fragmented amendments. One cannot expect to change legal culture with piecemeal legislation.

\footnotetext{
146 Discretion is not a popular word because under the former system it would be abused or used to harass. I am not even sure how much discretion can be reconciled with the current, expansive notions of the constitutional right to court.

147 The same view is presented under German law by Leipold, supra note 71, side notes 1-2.

148 See Rhee, supra note 140, p. 13. I believe that when talking about the theory behind and the model of judicial case management one cannot assume the incompetence of the judiciary. That would render any further discussion moot. Therefore, we must assume both good will and good skills. Cf. P. Oberhammer, T. Domej, Delay in Austrian Civil Procedure and the Legislator's Response [in]: C. H. van Rhee (ed.), Within a Reasonable Time: The History of Due and Undue Delay in Civil Litigation, Berlin: Duncker \& Humblot 2010, p. 269 (discussing the relationship between the skills of the judiciary and the nature of procedural provisions). 149 Cf. K. Weitz, Czy nowa kodyfikacja postępowania cywilnego [Should There Be a New Codification of Civil Procedure?], Państwo i Prawo [State and Law] 2007, issue 3, p. 21 (implementation of the [new] model of procedure is not possible through further amendments of the CCP because it is burdened with "the sins of ideology, that was used to form its foundation"). 150 "The attitude and habits of people, who constitute the judicial system, are far more important for its proper functioning than the technical perfection of the Code of Civil Procedure". F. Klein, supra note 141, p. 7 (own translation).
} 


\section{SOME RECOMMENDATIONS FOR THE POLISH LEGISLATOR}

Polish procedure needs effective pretrial rules ${ }^{151}$. This should not be understood as approval for an introduction of a full blown US-style discovery. There is no point in replacing a flat tire with a drained battery. The point is to improve the flow of information, structure the proceedings, and give the parties at least some tools to collect information independently and prior to trial, while at the same time redefining certain procedural rights e.g. the right to file a counterclaim.

The default rule should be a mandatory pretrial based on judicial discretion ${ }^{152}$. It could be verbal (pretrial hearing) or written (preparatory and closing submissions, evidentiary motions). Given the relative novelty of this idea in Polish civil procedure, and in turn the lack of legal culture, habits, and practice in that regard, provisions in the CCP should be relatively detailed ${ }^{153}$. These changes should go hand in hand with the change in how courts' calendars are managed and how the efficiency of a judge is assessed. Procedure is but a piece of a larger puzzle.

During the pretrial stage the parties and their attorneys should actively support the judge as a part of their duty to work towards the timely disposition of the case. This means parties should not be allowed to sabotage the course of the proceedings or, in principle, overcome the authority of the judge as far as management of the case is concerned. A system of sanctions is needed and simplicity of application is crucial. For example, if a pretrial conference has been set, parties or their attorneys must appear and be prepared to participate. To ensure enforcement, the court should be authorized to render a default judgment if a party does not comply.

In order to improve the efficiency of the proceedings, personal appearance should be moved from the first hearing at trial to the pretrial

\footnotetext{
151 This proposal is now at least over 10 years old. See P. Osowy, supra note 20, p. 158. This proposal is now over 10 years old. Cf. Łazarska, supra note 20, p. 57 (" $[\mathrm{A}]$ comprehensive discussion about the role and model of the judge in civil process has not yet taken place in Poland").

152 Additionally, some cases decided in special proceedings could be excluded (e.g. simplified proceedings).

153 Cf. Rules of the Court of Arbitration at PKPP Lewiatan (especially § 26), available at http://www.sadarbitrazowy.org.pl/upload/Rules1032012.pdf [last accessed: 17.04.2013].
} 
hearing. At such hearing the court should determine, in particular: 1) which facts are disputed and which are not, 2) the parties view on applicable substantive law, 3) the burden of proof and available evidence (sources of proof), and 4) the sequence of proof and evidence. The judge, through questions, should stimulate the parties to allege relevant facts and indicate evidence, so that these elements can be established properly. Moreover, evidentiary matters should also be discussed and resolved. Importantly, the court should also inform the parties about his or her initial view on the substantive law applicable to the case, in light of the allegations made. Although clearly time-consuming, these steps should ultimately improve the quality and duration of the trial, particularly the taking of evidence ${ }^{154}$.

The pretrial should conclude within 3 to 6 months following the submission of the answer. At this point the court would issue the order directing the case to trial, unless it believes the case can be decided by a summary judgment, i.e. without a trial ${ }^{155}$. Currently this is not possible under Polish law. Prior to that, the court could invite final briefs from the parties. Moreover, the order should stipulate the schedule of the trial and trial plan.

Any question of fact, evidence or law omitted from the order should be barred at trial, unless the moving party acted in good faith or properly discharged his or her duty to support the proceedings, the other party does not object, or other special circumstances exist (e.g. a clear mistake by the court). In addition, the party's right to amend the pleadings or to file a counter-claim should expire at that time.

\footnotetext{
154 This will also ensure the exchange of information between the participants and that the right to be heard is given full effect. Given the function of the courts in Poland, the parties should not learn about the court's view on substantive law from the written opinion following the judgment.

155 Obviously, not every case that is subject to regular procedure requires a trial. After pretrial hearing it may be that there is no dispute between the parties with regard to any material fact or all evidence is already available and sufficient to decide the case. Currently, deciding a case in a summary fashion in ordinary proceedings is not possible.
} 
